\title{
Changing Labor Market Conditions and Economic Development in Hong Kong, the Republic of Korea, Singapore, and Taiwan, China
}

\section{Gary S. Fields}

School of Industrial and Labor Relations and Department of Economics, Cornell University

In the newly industrializing economies (NIEs) of Hong Kong, the Republic of Korea, Singapore, and Taiwan (China), the entire working population has benefited from labor market institutions. The East Asian NIEs attained and maintained generally full employment, improved their job mixes, raised real earnings, and lowered their rates of poverty.

This article reaches two principal conclusions. First, labor market conditions continued to improve in all four economies in the 1980s at rates remarkably similar to their rates of aggregate economic growth. Second, labor market repression was not a major factor in the growth experiences of these economies in the 1980 s. It thus appears that labor market repression is neither necessary nor desirable for outward-oriented economic development. 
The newly industrializing economies (NIES) of East Asia grew at very rapid rates in the 1980s. During the decade, real per capita income grew by 64 percent in Hong Kong, by 122 percent in the Republic of Korea, by 78 percent in Singapore, and by 88 percent in Taiwan (China) (see table 1). This economic growth was fueled in large part by the growth of exports.

The purpose of this article is to determine how labor market conditions changed during this period of rapid, export-led growth. Two a priori hypotheses have been formulated. One is that wages and other forms of labor remuneration must be held down for East Asian exports to remain competitive in world markets. According to this view, it would be expected that any improvements in labor market conditions would be at a slower rate than overall economic growth. Wage repression would be necessary to prevent higher returns to labor from pricing the exports of the NIES out of competition in world markets, thereby slowing economic growth. The other prior hypothesis, contradictory to the first, is that growth would lead to ever-tightening labor markets and hence to higher returns to labor-perhaps explosively higher-as employers compete with one another for scarce workers to staff their growing enterprises.

Table 1. Growth in National Income and in Earnings in Four Newly
$\begin{aligned} & \text { Industrializing Economies in East Asia, } 1980-90 \\
& \text { (percent) }\end{aligned}$
\begin{tabular}{ccc} 
& \\
& Growth in real \\
ENP or GDP & Growth in real \\
Economy & earnings \\
\hline Hong Kong & $64.2^{\mathrm{a}}$ & $60.0^{\mathrm{c}}$ \\
Korea & $121.8^{\mathrm{b}}$ & $115.8^{\mathrm{d}}$ \\
Singapore & $77.5^{\mathrm{a}}$ & $79.8^{\mathrm{c}}$ \\
Taiwan (China) & $88.0^{\mathrm{b}}$ & $102.7^{\mathrm{c}}$ \\
\hline
\end{tabular}

\footnotetext{
a. GDP growth.

b. GNP growth.

c. Manufacturing.

d. Mining and manufacturing.

e. All industries.

Source: For Hong Kong: Government of Hong Kong (various years); for Korea: unpublished country data; for Singapore: Government of Singapore (1990); for Taiwan (China): Government of China (1991b).

This article assembles new data on what happened in Hong Kong, Korea, Singapore, and Taiwan (China) in the 1980s. Earlier evidence for the 1960s and 1970s (Fields 1984, 1985) is very clear. In the first stages of rapid economic growth, these economies moved closer to full employment; the job mix improved but real wages changed little. But once full employment was attained, as economic growth proceeded further, real wages rose rapidly in Hong Kong, Korea, and Taiwan (China), and the job mix improved.

These patterns can be understood by building upon the famous accounts of dualistic development offered by Lewis (1954) and by Fei and Ranis (1964). At first, the wage was high enough that there was an essentially unlimited supply of labor, $S_{0}$, at the prevailing wage, $W_{0}$ (figure 1 ). Rapid, export-led growth shifted the demand for labor curve rightward faster than the supply of labor curve shifted rightward; as a stylization of this, the supply of labor curve is held constant in the figure. As long as the excess supply persisted, the growing demand for labor (from $D_{1}$ to $D_{3}$ ) resulted in increased employment but not increased wages. However, once more labor was demanded at wage $W_{0}$ than was supplied, wages started to increase. As the demand for labor curves shifted to positions such as 04 and 05 , wages rose to $W_{4}$ and $W_{5}$, respectively.
} 
The process described above continued virtually without interruption in Hong Kong, Korea, and Taiwan (China), but in Singapore the picture is different. Real wages barely grew in the 1970s because of the strong repressive hand of the Singaporean government in the labor market. Wages there were held well below market-clearing levels for several years.

\section{Figure 1. Supply and Demand for Labor with Demand Increasing Faster Than Supply}

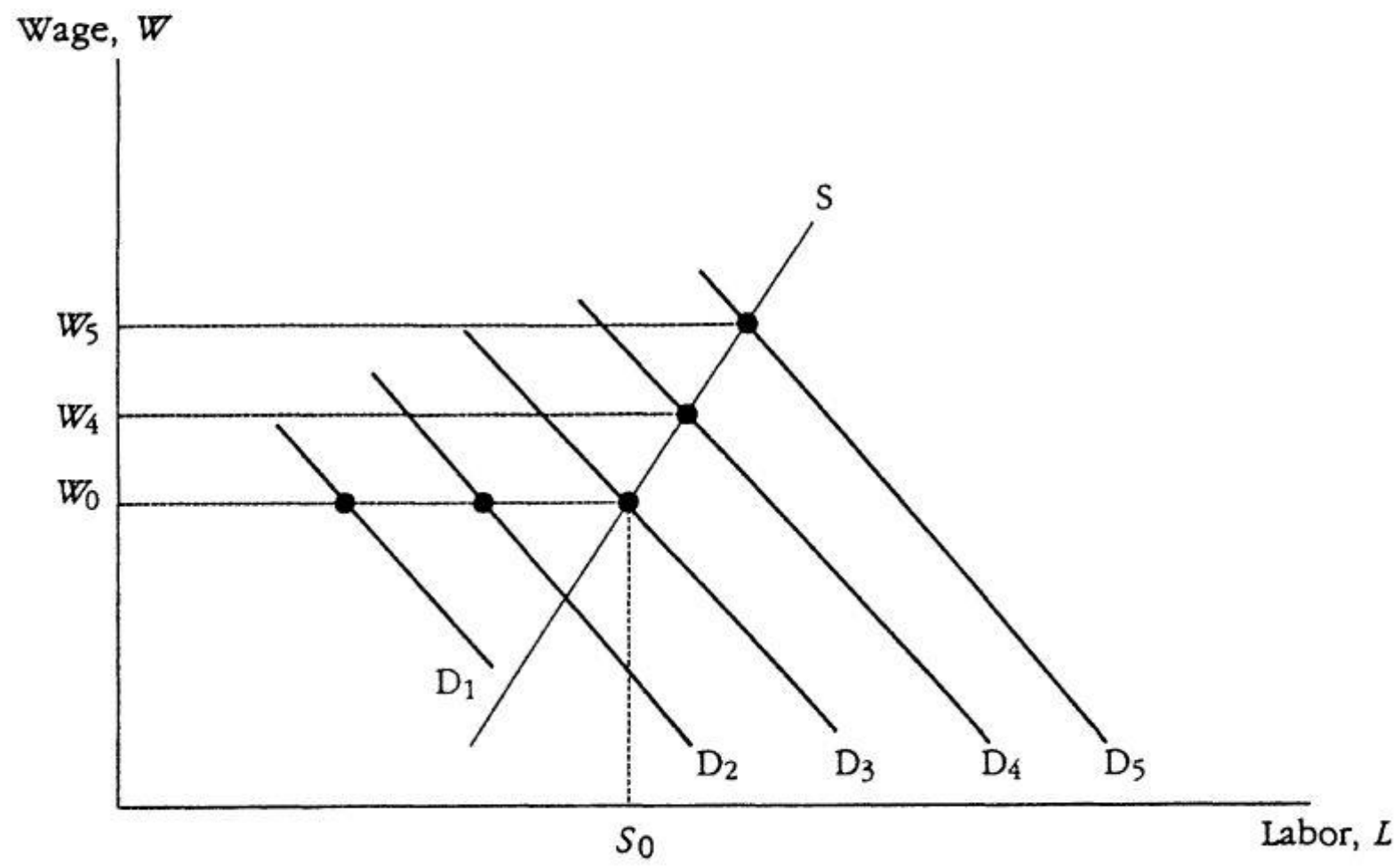

This article extends the earlier analysis of labor market conditions and income distribution in these four economies to cover the 1980s. I address two major issues. One is how conditions changed during the decade. I look at changes in five indicators: the rate of unemployment, the composition of employment, average real wages, income inequality, and absolute poverty. The second issue is labor market repression. Is there evidence of repression of wages or of labor unions? If so, how was this repression effectuated? Is there evidence that economic growth was affected, for better or for worse?

\section{CHANGES IN THE 1980s}

The data for all four economies tell a very consistent story: rapid economic growth led to improvements in labor market conditions (as measured by unemployment rates, job mix, and real earnings) and reductions in poverty. The workers in these economies benefited handsomely indeed from the economic growth that took place. Furthermore, the gains received by workers were remarkably similar to the gains in national income, as table 1 shows. East Asian economic growth did not leave workers behind. Annual data on changes in labor market conditions and income distribution in the 1980s for the four East Asian NIES are presented in table 2.

Hong Kong 
Table 2. Changes in Labor Market Conditions and Income Distribution in Four Newly Industrializing Economies in East Asia, 1980-90

\begin{tabular}{|c|c|c|c|c|c|}
\hline Indicator & Year & Hong Kong & Korea & Singapore & $\begin{array}{l}\text { Taiwan } \\
\text { (China) }\end{array}$ \\
\hline $\begin{array}{l}\text { I. Unemployment rate } \\
\text { (percent) }\end{array}$ & $\begin{array}{l}1980 \\
1981 \\
1982 \\
1983 \\
1984 \\
1985 \\
1986 \\
1987 \\
1988 \\
1989 \\
1990\end{array}$ & $\begin{array}{l}3.8 \\
3.5 \\
3.8 \\
4.1 \\
3.8 \\
3.3 \\
2.6 \\
1.9 \\
1.5 \\
1.4 \\
1.7\end{array}$ & $\begin{array}{l}5.2 \\
4.5 \\
4.4 \\
4.1 \\
3.9 \\
4.0 \\
3.8 \\
3.1 \\
2.5 \\
2.6 \\
2.4\end{array}$ & $\begin{array}{l}3.1 \\
2.9 \\
2.6 \\
3.2 \\
2.7 \\
4.1 \\
6.5 \\
4.7 \\
3.3 \\
2.2 \\
2.0\end{array}$ & $\begin{array}{l}1.2 \\
1.4 \\
2.1 \\
2.7 \\
2.4 \\
2.9 \\
2.7 \\
2.0 \\
1.7 \\
1.6 \\
1.7\end{array}$ \\
\hline $\begin{array}{l}\text { II. Employment composition } \\
\text { (percentage of total } \\
\text { employment) } \\
\text { A. Agriculture }\end{array}$ & $\begin{array}{l}1980 \\
1981 \\
1982 \\
1983 \\
1984 \\
1985 \\
1986 \\
1987 \\
1988 \\
1989 \\
1990\end{array}$ & $\begin{array}{l}\overline{2} .0 \\
- \\
- \\
- \\
\overline{1} \\
- \\
- \\
- \\
-\end{array}$ & $\begin{array}{l}34.0 \\
34.2 \\
32.1 \\
29.7 \\
27.1 \\
24.9 \\
23.6 \\
21.9 \\
20.7 \\
19.5 \\
18.3\end{array}$ & $\begin{array}{l}1.75 \\
1.49 \\
1.35 \\
1.34 \\
1.08 \\
1.11 \\
1.20 \\
0.87 \\
0.72 \\
0.71 \\
0.32\end{array}$ & $\begin{array}{l}19.5 \\
18.8 \\
18.9 \\
18.6 \\
17.6 \\
17.5 \\
17.0 \\
15.3 \\
13.7 \\
12.9 \\
12.8\end{array}$ \\
\hline B. Employees & $\begin{array}{l}1980 \\
1981 \\
1982 \\
1983 \\
1984 \\
1985 \\
1986 \\
1987 \\
1988 \\
1989 \\
1990\end{array}$ & $\begin{array}{r}88.5 \\
- \\
- \\
- \\
87.4 \\
- \\
- \\
-\end{array}$ & $\begin{array}{l}47.3 \\
47.2 \\
47.6 \\
49.5 \\
52.9 \\
54.1 \\
54.4 \\
56.2 \\
57.0 \\
59.1 \\
60.2\end{array}$ & $\begin{array}{l}85.0 \\
85.1 \\
84.7 \\
84.3 \\
84.4 \\
84.4 \\
84.4 \\
84.2 \\
85.4 \\
85.6 \\
87.5\end{array}$ & $\begin{array}{l}64.4 \\
64.3 \\
64.1 \\
63.8 \\
64.4 \\
64.1 \\
64.7 \\
66.7 \\
67.1 \\
67.4 \\
65.6\end{array}$ \\
\hline $\begin{array}{l}\text { C. Professional and } \\
\text { technical, } \\
\text { administrative and } \\
\text { managerial, clerical, } \\
\text { and sales occupations }\end{array}$ & $\begin{array}{l}1980 \\
1981 \\
1982 \\
1983 \\
1984 \\
1985 \\
1986 \\
1987 \\
1988 \\
1989 \\
1990\end{array}$ & $\begin{array}{c}\overline{-} \\
30.8 \\
- \\
- \\
\overline{-} \\
37.92 \\
- \\
- \\
-\end{array}$ & $\begin{array}{l}29.0 \\
29.2 \\
30.6 \\
32.1 \\
32.9 \\
34.3 \\
34.3 \\
34.1 \\
34.6 \\
35.4 \\
36.2\end{array}$ & $\begin{array}{l}42.9 \\
42.8 \\
44.2 \\
45.5 \\
46.5 \\
46.5 \\
46.2 \\
47.0 \\
46.1 \\
46.8 \\
60.0^{b}\end{array}$ & $\begin{array}{l}31.8 \\
32.7 \\
33.1 \\
33.4 \\
33.7 \\
34.2 \\
34.3 \\
35.1 \\
37.2 \\
38.5 \\
39.8\end{array}$ \\
\hline $\begin{array}{l}\text { D. Employed workers with } \\
\text { no schooling }\end{array}$ & $\begin{array}{l}1980 \\
1981 \\
1982 \\
1983 \\
1984\end{array}$ & $\begin{array}{c}- \\
- \\
-\end{array}$ & $\begin{array}{l}- \\
- \\
-\end{array}$ & $\begin{array}{l}25.2 \\
24.5 \\
24.9 \\
23.3 \\
20.7\end{array}$ & $\begin{array}{l}9.8 \\
9.4 \\
8.9 \\
8.9 \\
8.6\end{array}$ \\
\hline
\end{tabular}




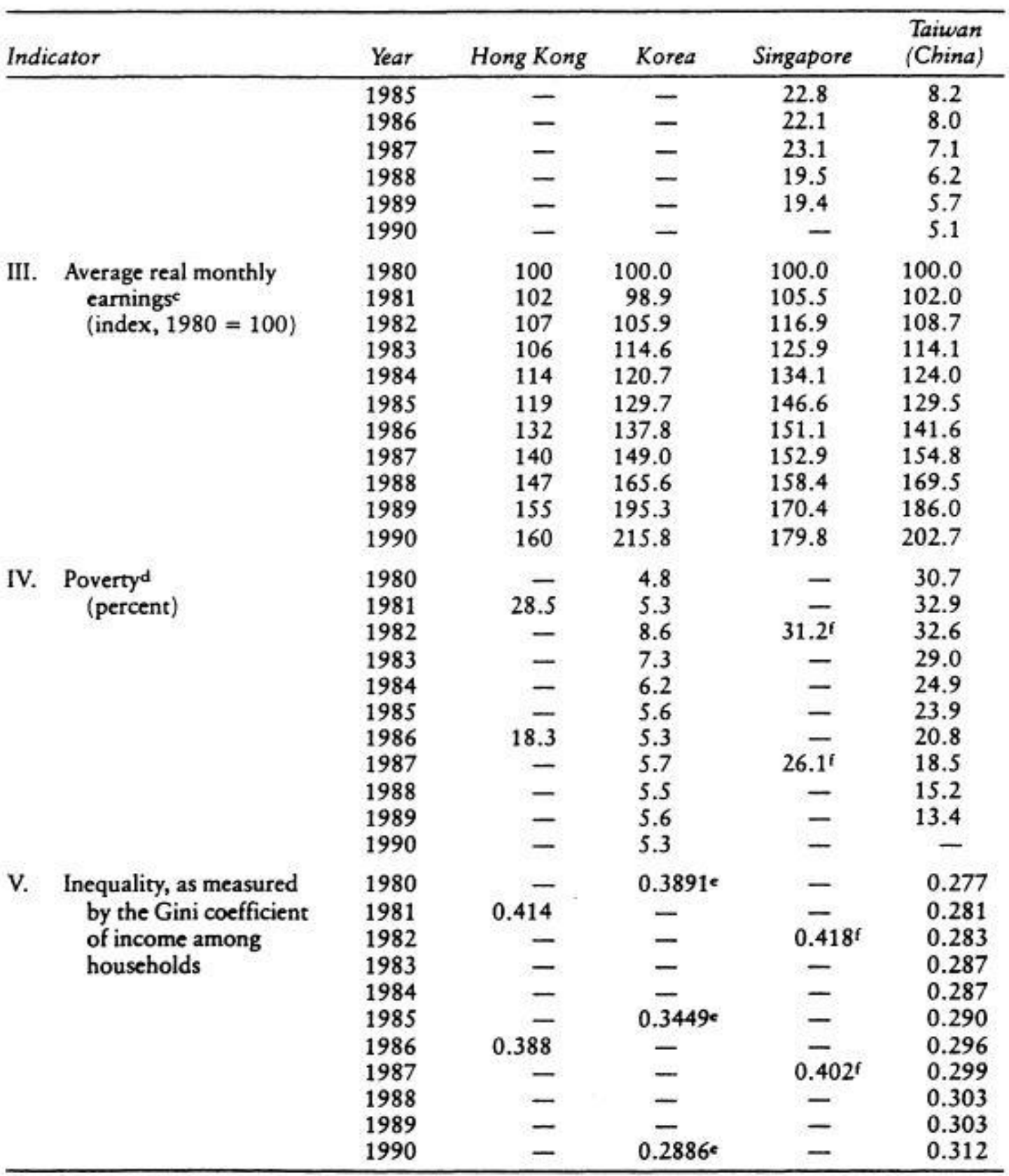

- Not available.

a. Total employed includes unemployed workers who have previously held jobs.

b. Includes service workers.

c. For Hong Kong the data are wages in manufacturing; for Korea, earnings in mining and manufacturing; for Singapore, earnings in all industries; and for Taiwan, earnings in manufacturing.

d. Percentage of households with monthly income less than HKS2,000 (1981 prices) for Hong Kong, S\$1, 000 (1982/83 prices) for Singapore, and NT\$200,000 (1986 prices) for Taiwan. For Korea the data are the percentage of the total population receiving livelihood protection.

e. The Gini coefficient of urban income.

f. Data refer to fiscal year.

Source: For Hong Kong: Government of Hong Kong (1981: table 2.9; 1986a; 1986b; various years) and unpublished country data. For Korea: Government of Korea (various issues; various years; 1988); Y.-B. Park (1992a; 1992b); and unpublished country data. For Singapore: Fields (1985) and Government of Singapore (various years). For Taiwan: Government of China (various years; 1991b).

In Hong Kong, real gross domestic product (GDP) per capita grew by 64.2 percent in the 1980s. 
This growth was quite uneven, however; in several years, the growth rates were below 2 percent, whereas in several others years, they ranged from 9 to 13 percent.

It would be expected that when growth is uneven, unemployment would be variable. Indeed, in Hong Kong's economic slowdown of 1982, the unemployment rate increased to 4 percent. But subsequent economic growth brought unemployment down, and it has been below 2 percent of the labor force since 1987.

The tight labor market is also manifested in an improved job mix. Agriculture's share of total employment, already very low, fell even further. A larger share of workers came to be employed in professional, administrative and managerial, clerical, and sales occupations. The share of paid employees in total employment fell, however, because of a substantial increase in the fraction of self-employed. Information is not available on the changes in workers' earnings in these different occupational categories. One other indicator of improved job mix is the educational attainments of workers. Because of a change in the way this information is reported, however, comparable data across years are not available for Hong Kong.

The continued tightness in the labor market also shows up in real wages. Real wages grew by 60 percent in Hong Kong during the 1980s, slightly below the rate of growth of real per capita GDP (64.2 percent). The growth in real wages caused the poverty head-count ratio to fall from 28.5 percent in 1981 to 18.3 percent in 1986. Income inequality, already at moderate levels in Hong Kong, fell further-from a Gini coefficient of 0.414 in 1981 to a Gini of 0.388 in 1986.

\section{The Republic of Korea}

In the 1980s the Korean economy continued its remarkable progress in improving labor market conditions. The labor market, already tight, became even tighter. The unemployment rate, which had hovered around 4 percent in the 1970s and had reached 5.2 percent by 1980 , began falling. It fell to 3.1 percent by 1987 and to 2.4 percent by 1990 . The job mix also continued to improve as the increase in job opportunities for workers in the better-paying sectors and occupations continued to outpace the growth of labor supply. In the 1980s agriculture as a share of total employment continued to decline, falling almost by half. The fraction of workers engaged as paid employees (as opposed to self-employed or unpaid family workers) grew from 47.3 to 60.2 percent. The fraction of workers employed in the top occupations (professional, technical, administrative and managerial, clerical, and sales) increased by 24.8 percent. The educational composition of the labor force also improved. The percentage of employed workers with only primary schooling fell by nearly half.

Real earnings doubled within the decade in Korea. By 1990 real average earnings in mining and manufacturing had reached 215.8 percent of their 1980 levels. The growth of real earnings over the decade (115.8 percent) was virtually the same as the growth of real per capita gross national product (GNP, 121.8 percent). The 7.7 percent average real growth rate of earnings was extremely high. Overall, in the twenty-five years between 1966 and 1990, real earnings in Korea increased sixfold among a fully employed labor force-the best record of any economy in the world during that period.

Information on poverty is something of a problem in Korea. What is available is information on the number of "livelihood protection persons;' that is, individuals who receive assistance from the Ministry of Health and Social Affairs in the form of home care, institutional care, or consumption assistance. The percent- age of Koreans receiving such assistance was 4.8 in 1980, rose to 8.6 during the recession of the early $1980 \mathrm{~s}$, and then fell to 5.6 by 1985 , where it has more or less remained since. It would be better to have information on the fraction of households or individuals with income or consumption below a constant real poverty line, but to the best of my knowledge such information is not yet available.

In terms of relative inequality, there is a strong divergence between what people perceive and what the numbers show (Choo 1992; Leipziger 1992). Although it is thought that the very rich in Korea have gotten richer even faster than have other Koreans (which would produce an increase in inequality of total incomes), the available evidence shows that income inequality in Korea fell in the 1980s (see the 
studies by Choo 1992; Leipziger 1992; and Y.-B. Park 1992a, 1992b). Topel and Kim (1992) attribute the equalization of incomes to the equalization of human capital levels and to a sharp narrowing of the differential in wages between college graduates and grade school graduates. Kwark and Rhee (1992) show that this equalization was caused both by the narrowing of the occupational wage structure and by the fact that many of the newly educated workers moved down in the job ladder to take lower-level jobs than previously educated workers had taken.

Overall, the record for Korea is one of extraordinarily rapid and sustained improvements in labor market conditions.

\section{Singapore}

Except for a recession in 1985 and 1986, the Singaporean economy grew rapidly in the 1980s. As a result, per capita GDP was 77.5 percent higher at the end of the decade than it was at the beginning.

The unemployment rate mirrors the country's growth performance. Unemployment was around 3 percent until the mid-decade recession raised it to 6.5 percent. With the economic recovery, unemployment again fell, reaching just 2.0 percent by 1990 .

The job mix continued to improve in Singapore, albeit slowly. The share of workers in professional and technical, administrative and managerial, clerical, and sales occupations rose from 42.9 percent at the beginning of the decade to 46.8 percent by the end. The fraction of total employment accounted for by paid employees (as opposed to self-employed or unpaid family workers), already high, grew even higher: from 85.0 percent at the beginning of the decade to 87.5 percent by the end. The labor force continued to become better educated, and the fraction of employed workers with no schooling fell by nearly one-fourth. One other commonly used indicator of job mix is the percentage of the labor force in agriculture. In Singapore, however, agriculture has become such an insignificant percentage of the labor force (just 0.3 percent of the labor force at present) that this information is of little value.

Real earnings in Singapore grew by 79.8 percent during the 1980s. This growth rate was virtually the same as the growth rate of real per capita GDP during the decade (77.5 percent). Parity between growth in real earnings and growth in real per capita GDP was in marked contrast to Singapore's experience in the 1970s, during which time earnings grew by just 2 percent annually while the economy was growing at 9 percent. The reason for the difference between the 1970s and 1980s was that Singapore abandoned its earlier practice of wage repression.

Information on inequality is available only for scattered years. According to data from Government of Singapore (various years, 1990), the Gini coefficient was 0.418 in 1982-83 and 0.402 in 1988-89. Whether this decline in inequality is economically meaningful is debatable; what can be said

clearly from the data is that inequality in Singapore did not increase in the 1980s.

Poverty continued to fall. The proportion of households with incomes below S\$1,000 a month (in 198283 prices) declined from 31.2 percent in 1982-83 to 26.1percent in 1987-88.

\section{Taiwan (China)}

The economy of Taiwan (China) maintained its high growth rate throughout the 10980s. Real per capital GNP was twice as high in 1991 as it had been in 1980. But the slower growth rate in the early 1980s caused the unemployment rate to move up gradually from 1.2 to 2.9 percent before coming back down to 1.7 percent. The job mix continued to improve over the decade: there was a one- third decrease in agriculture's share of total employment, a small increase in the number of paid employees as a percentage of total employment, a larger increase (from 31.8 to 39.8 percent) in the share of high-level workers (professional and technical, administrative and managerial, clerical, and sales workers) as a percentage of total employment, and a halving of the percentage of employed workers who had no schooling. Real earnings again doubled, growing even faster between 1980 and 1990 (102.7 percent) than did real per capita GNP ( 88.0 percent). The workers of Taiwan benefited handsomely from economic growth in the 1980s. 
Not surprisingly, given the rapid growth of GNP and of earnings, poverty dropped sharply from 30.7 percent of households in 1980 to 13.4 percent by 1989. As for inequality, although Taiwan has had the world's most equal distribution of income, the 1980s were a time of inexorable increase in inequality. The Gini coefficient rose from 0.277 to 0.312 , a fairly substantial increase in so short a time. The real incomes of the upper-income groups more than doubled while those of the lower-income groups fell just short of doubling, hence the percentage increase for the rich was larger than for others.

\section{LABOR MARKET REPRESSION}

It is sometimes said that export-led industrialization can succeed only if labor's real earnings do not rise. The data presented in the previous section show conclusively that this was not the case in the four East Asian NIES. Instead, economic growth led by increasing export penetration in world markets is quite consistent with rising real earnings of labor.

Nonetheless, it may still have been the case that one or more of the East Asian NIES developed by limiting the growth of wages or the power of organized labor or both, with the aim of maintaining international competitiveness and facilitating economic growth. In what follows, I use the term "labor market repression" to denote either the restraint on wage growth ("wage repression") or the restraint on organized labor ("labor repression").

Could wages have risen while at the same time being repressed? Did public policy weaken the bargaining strength of organized labor, causing wage in- creases to be less than they would otherwise have been? What were the indications of the presence of labor market repression? It is beyond the scope of this article to provide complete answers to these questions. As a referee correctly notes, a full answer would require building a model simulating the path of hypothetical wages in the formal sector of the economy under free labor market conditions and then comparing this against the actual path. Nonetheless, two kinds of evidence are informative.

The first is direct evidence on the operation of the repressive forces, that is, "the smoking gun approach." The direct government role in wage setting in Singapore and the passage of industrial relations legislation weakening trade union bargaining power in Korea fall into this category. It might be argued

\section{Figure 2. The Effects of Wage Repression on the Labor Market}

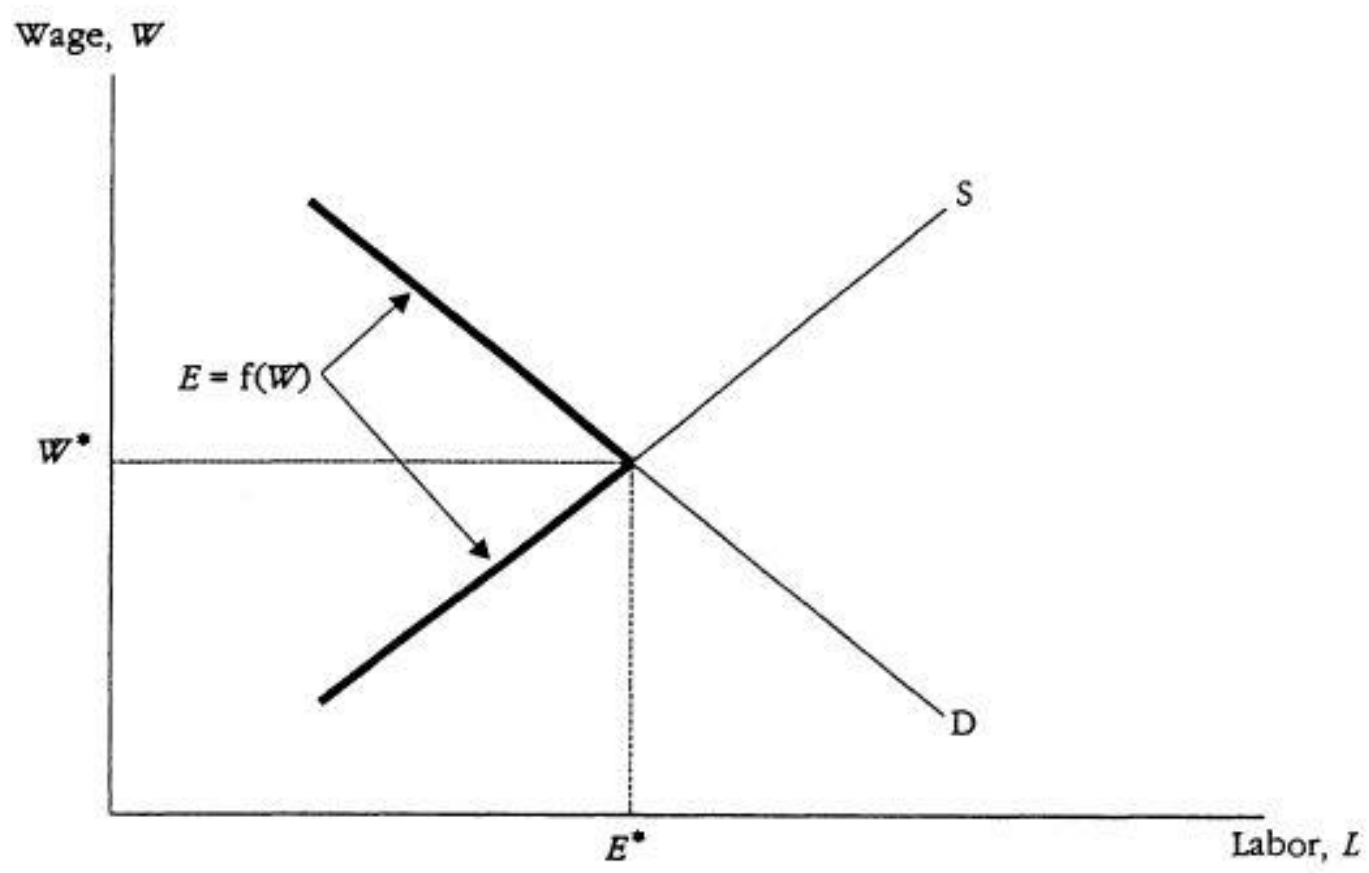


that these institutions, although potentially repressive, may in fact have made little difference. This is where a second kind of evidence comes in, that is, the pattern of wages and employment in labor markets.

Wage repression, if serious enough, would be expected to have the following effect: when the wage is suppressed, less labor is supplied than at the market- clearing wage, causing employment to fall because of the resultant labor short- ages. Figure 2 shows this, along with the well-known result that a wage above the market-clearing level also reduces employment. Thus, employment is maximized when the wage is at the market-clearing level rather than above or below it. Singapore's wage-repression policy curtailed employment and therefore hampered economic growth. This is illustrated in figure 2 for a country that has moved beyond the surplus labor stage to the stage where its labor market is of the neoclassical type. Wage repression lowers economic growth by reducing the neoclassical type. Wage repression lowers economic growth by reducing the amount of labor supplied, which reduces the amount of labor input $(L)$ in a standard production function of the type $Q=f(K, L)$, causing less output to be produced than otherwise.

Labor market repression can operate in another way, which is to weaken labor's bargaining power. In this case, labor's share of national output would be expected to be low, or wages would be expected to rise at a slower rate than output. This was not the case in the East Asian NIES, even in Korea, where labor repression is said to have been practiced.

\section{Hong Kong}

Hong Kong does not appear to have had any important labor market repression or wage distortions. Hong Kong's labor market institutions are very close to laissez-faire (Cheng 1977; Hsia and Chau 1978; Rabushka 1979; Turner 1980; Chow and Papanek 1981; Young 1989). Hong Kong does not have an active economic policy, either in general or with respect to the labor market. The government is not involved in wage determination. In particular, Hong Kong has no minimum wage or special provisions about what foreign-owned firms must pay, and there is no mechanism by which the government can repress wages, for instance, by exercising power through a national wages council as in Singapore. The public sector does not pay a wage premium over the private sector. Unions are permitted, but they are neither favored nor discouraged by public policy. Workers have exhibited little enthusiasm for joining unions or for bargaining collectively in pursuit of improved working conditions. Although strikes are allowed in the private sector, few unions have strike funds apparently because they have little inclination to strike. Hong Kong's labor code has little effect on the labor market. For example, employers are required to give only seven days' advance notice of layoffs or dismissal and must give only seven days worth of severance pay.

In sum, Hong Kong's situation is one of labor peace with market-determined wages and employment conditions.

\section{The Republic of Korea}

Several authors have characterized labor market conditions in Korea as being market-determined (Moran 1976; Lindauer 1984; Fields 1985; Richardson and Kim 1985; Castaneda and F.-K. Park 1986; Fields and Wan 1989). This conclusion is based on the apparent lack of forces that push wages appreciably above market-clearing levels and on the attainment of generally full employment, ex- cept temporarily during brief economic recessions.

Whether Korean wages were below market levels is · widely debated. The evidence is that real wages in Korea rose rapidly, faster even than GNP growth: between the mid-1960s and the mid-1980s, real wages in manufacturing (which has been the engine of Korean economic growth) rose at an annual rate of 8.1 percent while real per capita GDP grew by 6.9 percent (Lindauer 1991: 19, 29). Some authors (Deyo 1989; Vogel and Lindauer 1991) claim that labor repression was in force in Korea. Now however, according to Vogel and Lindauer (1991: 5-6), "Korea is currently in the midst of a transition away from a historically repressive system of labor control that is no longer viable .... It [is] impossible to maintain 
the old system of tight labor control backed by state force:' Possibly, wages would have risen even more rapidly if labor had been less controlled, but we cannot know.

S.-1. Park (1992) has prepared a comprehensive review of the stages in Korea's industrial relations practices. There were three mechanisms by which labor repression may have been practiced in Korea: restrictions on unions, government jawboning for private firms to limit wage increases, and restrictions on credit to noncompliers. Until 1987 labor unions in Korea were very weak. Only about 15 percent of the workers were unionized (S.-1. Park 1992). The powers of unions were limited in a number of ways: only enterprise unions were permit- ted; national unions and the nationwide Federation. of Korean Trade Unions were under the control of the government and did not intervene in collective bargaining; strikes could be ended by police action, arrest of union leaders, or both; and in the event of a labor dispute, arbitration was compulsory. Consequently, unions had little economic power, and wage growth was kept down as a result of this deliberate attempt by previous Korean governments to weaken unions. For accounts of the pre-1987 period, see You (1990) and Lindauer (1991).

Another way in which government may have exercised labor repression was through jawboning, both open and covert. The government issued open "guide- lines" for wage increases. These were "enforced" behind the scenes through the credit system:

Acting through the Bankers' Association of Korea, the government also tried to keep wage increases low by having banks restrict credit for firms which increased wages beyond government guidelines. ... Whenever there was a more explicit confrontation over this issue, the government would say 'There is no official guideline. It is just a suggestion on the part of the government.'

(Nam 1984: 73-74)

Given the heavy involvement of government in the Korean economy, many labor economists in Korea (for example, Bai 1985) have viewed efforts at jawboning to lower wages as repressive. Several pieces of evidence suggest that unions were indeed weak in Korea, at least until 1987, and that wage growth may have been slowed as a result of the various government-imposed restrictions.

- S.-1. Park (1980) found that membership in a union was not a significant determinant of earnings in Korea in the 1970s-a result that could only be found if unions were too weak to have had much of an economic impact.

- For the 1978-85 period, Topel and Kim (1992: figure 9c) found no relation between wage growth and employment growth for different manufacturing industries. This means that aggregate wage groWth was neutral among sectors, leading Topel and Kim to conclude that there is "one labor market in Korea" and that unions did not play an important role in raising the wages of their members in relation to other workers in the economy.

- You (1990: 110-11) shows that three periods of intense political repression (1961-64, 1971-72, and 1980-82) were also times of negative or sluggish real wage growth. These were, however, times of overall economic improvement. You interprets this as showing that "the labor rights situation has had a substantial impact on wage formation."

Various authors have also commented on the growth of wages and of productivity, with inconclusive results. Some authors find evidence of wage repression. Topel and Kim (1992, figure 1) find that in the early 1980s real wage growth lagged far behind productivity growth. They conclude (p. 8) that "government efforts to suppress wage growth-at least for less skilled workers-seem to have been successful" in those years. Mazurndar (1990) shows that for the period 1967-86 Korea experienced a "sustained and substantial rate of increase in labor productivity" (p.16). He finds, however, that real wages grew more slowly than productivity. He interprets this as evidence of "the importance of state paternalism in wage negotiations in the formal sector in keeping real wage increases in line with productivity growth but somewhat below it in most periods. . . . It was also eminently successful in drastically slowing down or even halting real wage growth during the short-run periods of crisis." $\mathrm{He}$ terms this wage-productivity relationship "healthy"-a characterization not shared by everyone. 
Other wage-productivity comparisons give a very different picture. Lindauer (1991) indicates that between 1965 and 1984 real wage growth in Korea kept pace with productivity increases. You (1992: 21, 31 ) observes that over the long run, the growth rate of real wages in Korean manufacturing ( 8 percent a year) was higher than the growth rate of productivity (6 percent a year). You concludes that "Korea's success in rapid industrialization and, in particular, manufacturing exports was therefore not based on low wages. Rather, it was achieved with an extraordinarily fast real wage growth. ... The rapid rise in real wages in Korea is a result of the rapid productivity growth and the rapid growth in demand for labour." (Emphasis added.)

Data on labor's share in national income help resolve the conflict over whether there was labor market repression. Y.-B. Park (1992a: 25) shows that employee compensation as a percentage of national income increased from 31.8 percent in 1965 to 39.7 percent in 1970, to 51.6 percent in 1980, and to 56.3 percent in 1989. Korean labor cannot have been repressed too badly.

It is important to note that all of the preceding evidence predates 1987, a significant year in Korea's labor history because on June 29 of that year, Korea's industrial relations system was substantially reformed. As part of a larger political liberalization, the government granted new rights. Most important, the government agreed to keep out of labor-management negotiations, allowing the two sides to bargain autonomously.

The 1987 reforms had two immediate impacts: increased strike activity and greater union organizing. A rash of strikes immediately followed the 1987 liberalizations; there were as many strikes in Korea in July and August of 1987 as there had been in the preceding twenty-five years combined. But the industrial relations climate soon stabilized: the number of labor disputes fell from 3,749 in 1987 to 1,873 in 1988 and to just 234 in 1991. Meanwhile, the trade union movement expanded rapidly. Between July 1987 and December 1989 the number of organized establishments tripled, and union membership doubled. But even so, only 17.4 percent of all employees are covered by collective bargaining agreements.

Union activities remain limited. Korea's Trade Union Act maintains the principle of "exclusive jurisdiction," that is, that each group of workers is eligible for representation only by an established union, thus preventing competitive organizing drives. The Federation of Korean Trade Unions remains the only legally sanctioned trade union federation. This renders illegal the operations of more radical and independent unions and the council into which they are organized (the National Council of Trade Unions) and weakens the labor movement. Although employees in public enterprises have now received the same labor rights as private sector workers, teachers and civil servants still do not have the right to join trade unions or to strike. Major revisions to Korea's labor laws were passed by the National Assembly in 1989 but vetoed by the president. Since 1990, the government has once again tried to influence collective bargaining outcomes by pushing for prompt settlement of wage negotiations and by urging that wage increases be kept within single digits. (S.-1. Park 1993 characterizes the post-1989 period as one of "selective intervention;' in contrast to 1987-89, which he characterizes as "laissez-faire.") These limitations on union organizing and collective bargaining notwithstanding, two leading Korean labor economists conclude that Korean workers "have gained fuller freedom in exercising their basic labor rights to organize, to bargain collectively, and to strike" (F.-K. Park and Y.-B. Park 1991:3).

The greater liberalization of Korea's industrial relations system is reflected in changed labor market conditions. Between 1986 and 1991 the real wage in the manufacturing sector increased by 67.7 percent while productivity increased by only 40.6 percent (Y.-B. Park 1992b: 13). More recently, the onedigit policy failed, and wages rose by 18.8 percent in 1990 (20.3 percent in manufacturing). Interestingly, the wage increases reported to the government averaged just 9.1 percent. This was the increase of basic wages, excluding increases in bonuses, special wages, and other fringe benefits. Now the government is trying to implement a "total wage system;' which it seeks to enforce through financial sanctions in credit allocation and through safety and health inspections. The effect of this system is not yet clear.

That growth in real wages was faster than growth in productivity was oppo- site to the earlier mixed evidence reported for the period before the liberalization of Korea's industrial relations system. The faster growth in real wages suggests that the additional support provided to unions, and to workers more 
generally, enabled wages to increase at higher real rates than they had during the earlier, more repressive period. It is impossible to say which was more important-the strengthening of organized labor or the tightening of labor market conditions- in producing these wage increases. Undoubtedly both played a role.

\section{Singapore}

Detailed accounts of the Singapore labor relations experience may be found in Pang (1988), Lim (1990), and Pang and Lim (1989), from which the following information is taken. The early labor history of Singapore was marked by an emphasis on labor peace. Communist unions were disbanded and strikes out- lawed. Unions were free to bargain over wages. Until 1972, wages in Singapore were determined largely by market forces.

But in 1972 the National Wages Council (NWC) was set up to make annual recommendations for wage increases. Equal representation was given to management, the National Trade Union Congress (NTUC), and government. The relationship between the NTUC and the government was, and still is, extremely close. That fact, along with the very strong role of government in Singapore, meant that the NWC's "guidelines" were nearly always followed. And the NWC recommended very modest wage increases. Between 1972 and 1979, real wages rose by 2 percent while real GDP rose by 9 percent (Fields 1985).

The purpose of the 1972-79 wage repression was to maintain the international competitiveness of Singapore's labor-intensive export industries. The Labor Minister in the mid-1970s, Mr. Ong Pang Boon, said at that time:

Our working population may well have to undergo a period of belt- tightening all round. . . It is dear that an essential element in our new strategy must be a tighter grip on wage increases. . . If we do not quickly and willingly change to low gear on the wages front, we shall further discourage investment and aggravate the unemployment problem. (The Straits Times, February 29, 1976)

But the wage repression policy went too far, and the labor market tightened to the point where labor shortages became severe. Employers wanted to offer higher wages to attract the workers they needed but were prevented by the NWC guidelines from doing so. Immigration quotas were loosened somewhat to meet a fraction of the excess demand, but labor shortages worsened. The overall result, unfortunately, was not only that economic growth was curtailed but also that the rate of improvement of living standards slowed down.

By 1979 the failures of the wage repression regime were evident. In that year the government announced a policy of "wage correction" aimed at alleviating labor shortages and restructuring the economy away from labor-intensive industries and toward capital-intensive and skill-intensive ones. Under the wage-correction policy, real wages were supposed to rise at double-digit rates. In the event, this did not happen; wages rose at a real rate of 7 percent, in line with real GDP growth but no faster.

In 1982 and 1983 the role of the NWC in wage determination was substantially weakened. The government removed itself from the NWC (which became bipartite), and the guidelines became less central to the wage-determination process (Lim 1990: 83). In 1985 real GDP declined by 1.7 percent, and 90,000 jobs were lost. The government imposed a temporary wage freeze, which lapsed a year later. Except for the recession year of 1985, the Singaporean government has kept out of the wage-setting process.

In summary, for purposes of assessing the issue of wage repression, the history of Singapore may be divided into four periods: reliance on market wage determination before 1972, wage repression from 1972 to 1979, wage correction from 1979 to 1982, and a return to market wage determination since then.

\section{Taiwan (China)}


In Taiwan (China) real GDP and real manufacturing earnings grew at very similar rates in the 1980s (88.0 and 102.7 percent, respectively) while the unemployment rate remained around 2 percent. This suggests that Taiwan had neither wage repression nor artificial wage increases. Wages seem to have been set by supply and demand.

The supply-demand explanation is consistent with the observation by several writers that such forces as unions, minimum wages, public sector pay policy, multinational corporations, and labor codes are of little importance in Taiwan (Kuo 1983: chap. 4; Hou and Wu 1985: 6; Wu 1986: 51; Kuznets 1988: 527-29; Deyo 1989; Li 1989: 143; and Fields and Wan 1989: 1477). Unions have limited power for a number of reasons: market factors (the Hicks-Marshall laws of derived demand), the principle of exclusive jurisdiction in labor relations, the prohibition on the Chinese Federation of Labor from engaging in collective bargaining, and worker disinterest in general. As a result of the weak union movement, unionized employees are estimated to earn only 0.3 to 1.9 percent more than comparable nonunion employees (Lin 1989). Minimum wages are a nonissue, both because they are quite low (less than half the average wage) and because no employer has ever been reported for violating the scale (Chang 1989). Taiwan introduced the Basic Labor Standards Law in 1984; but although it came under attack for the possible difficulties it might cause, it is judged to have had little effect up to now.

The evidence in Taiwan is of a remarkably integrated labor market. Manufacturing wages are only 20 percent higher than agricultural wages (compared with wages that are 150 percent higher in Colombia and Jamaica). 4 The data also show no significant correlation between the growth rate of earnings in various industries and the growth of output, of employment, or of exports in those industries (Fields 1992: 413). This is because the labor markets in the various sectors are so closely tied together that changes in earnings are determined by the growth of the economy as a whole and not by economic growth in any particular sector. By contrast, output growth is related to a sector's rate of employment growth. This highly significant correlation may be interpreted as shifting the demand for labor curves that determine firms' willingness to grant wage in- creases to attract or retain workers.

In sum, Taiwan's labor market closely approximated the competitive labor market scenario. Wage repression was not practiced there.

\section{III.CONCLUSIONS}

This article reaches two principal conclusions. The first is that labor market conditions continued to improve in all four economies in the 1980s at rates remarkably similar to their rates of aggregate economic growth. The second is that although wage repression was not a major factor in the growth experiences of these economies in the 1980s, the weakening of the labor movement was a significant factor in one country, the Republic of Korea, at least until 1987.

Is labor market repression necessary for successful economic growth? The answer suggested by the available evidence is no. Labor market repression is not necessary, because Taiwan (China) and Hong Kong developed very nicely without labor market repression. Is labor market repression desirable? Again, no. Wage repression had such negative economic consequences in Singapore in the 1970s that it was abandoned and has not been reinstituted since. Korea's labor repression became untenable, so that in 1987 that country instituted a general political liberalization that included fundamental changes in industrial relations practices.

Nonetheless, there are those who argue that wages should be held down in the future lest economic growth be stifled because of the loss of export competitiveness. I would ask two questions of those who hold such views. First, if wages are held down, how would companies deal with the labor shortages that would be expected to result? Would economic growth be curtailed? Second, what is the point of export-led growth if working people do not benefit from it? Why achieve growth?

The general labor market lesson coming from the East Asian NIES is that the entire working population can and has benefited from labor market institutions. Labor market institutions enabled employment and earnings to be pulled up rapidly, increasing demands for labor emanating from exportled growth. The records of these economies in attaining and maintaining generally full employment, 
improving their job mixes, raising real earnings, and lowering their rates of poverty are the envy of the rest of the developing world. 


\section{REFERENCES}

The word "processed" describes informally reproduced works that may not be commonly available through library systems.

Bai, Moo-Ki. 1985. "Industrial Development and Structural Changes in the Labor Market: The Case of Korea." In Moo-Ki Bai and Chang-Nam Kim, eds., Industrial Development and Structural Changes in the Labor Market: Korea and Southeast Asia. Tokyo: Institute of Developing Economies.

Castaneda, Tarsicio, and Fun-Koo Park. 1986. "Structural Adjustment and the Role of the Labor Market: The Case of Korea." Paper presented at the Conference on Structural Adjustment in a Newly Industrialized Country: Lessons from Korea, Washing- ton, D.C., June 17-18. Processed.

Chang, Ching-huei. 1989. "A Study on the Labor Market in Taiwan." Paper presented at the 1989 Joint Conference on the Industrial Policies of the Republic of China and the Republic of Taiwan, Taipei, Taiwan (China). Processed.

Cheng, Tong Yung. 1977. The Economy of Hong Kong. Hong Kong: Far Eastern Publications.

Choo, Hakchung. 1992. "Income Distribution and Distributive Equity in Korea." Paper presented at the Symposium on Micro-Social Issues in South Korea, University of California at San Diego, June. Korea Development Institute, Seoul. Processed.

Chow, Steven C., and Gustav Papanek. 1981. "Laissez-faire, Growth, and Equity- Hong Kong." Economic Journal 91(362, June):466-85.

Deyo, Frederic C. 1989. Beneath the Miracle: Labor Subordination in the New Asian Industrialism. Berkeley: University of California Press.

Fei, John C. H., and Gustav Ranis. 1964. Development of the Labor Surplus Economy. Homewood, Ill.: Irwin.

Fields, Gary S. 1984. "Employment, Income Distribution and Economic Growth in Seven Small Open Economies." The Economic journal 94(373, March):74-83.

-----. 1985. "Industrialization and Employment in Hong Kong, Korea, Singapore, and Taiwan." In Walter Galenson, ed., Foreign Trade and Investment: Economic Growth in the Newly Industrializing Asian Countries. Madison, Wis.: University of Wisconsin Press.

-----. 1992. "Living Standards, Labor Markets, and Human Resources in Taiwan." In Gustav Ranis, ed., Taiwan: From Developing to Mature Economy. Boulder, Colo.: Westview Press.

Fields, Gary S., and Henry Wan, Jr. 1989. "Wage-Setting Institutions and Economic Growth." World Development 17(9):1471-84.

Government of China. Various years. Report on Survey of Personal Income Distribution in Taiwan Area of the Republic of China. Taipei, People's Republic of China: Directorate General of Budget, Accounting, and Statistics.

------. 1991a. Statistical Yearbook of the Republic of China 1991. Taipei, Republic of China: Directorate General of Budget, Accounting, and Statistics.

-----. 1991b. National Income in Taiwan Area of the Republic of China 1991. Taipei, Republic of China:

Directorate General of Budget, Accounting, and Statistics.

Government of Hong Kong. 1981. Hong Kong 1981: Census Main Report. Census and Statistics Department, Hong Kong.

-----. 1986a. Hong Kong 1986 By-Census: District Summary Tables. Census and Statistics Department, Hong Kong.

-----. 1986b. Hong Kong 1986 By-Census Summary Results. Census and Statistics Department, Hong Kong.

-----. Various years. Hong Kong in Figures. 1985-1991 editions. Census and Statistics Department, Hong Kong.

Government of Korea. Various years. Annual Report on the Economically Active Population Survey. National Statistical Office, Seoul. 
-----. Various issues. Monthly Statistical Bulletin. National Statistical Office, Seoul.

-----. 1988. Economic Statistics Yearbook. National Statistical Office, Seoul.

Government of Singapore. Various years. Report on Household Expenditure Survey. Department of Statistics. Singapore.

-----. 1990. Yearbook of Statistics. Department of Statistics. Singapore.

Hou, Chi-Ming, and Hui-Lin Wu. 1985. "Wages and Labor Productivity in Taiwan." Industry of Free China 63(May): 1-7.

Hsia, Ronald, and Laurence Chau. 1978. Industrialization, Employment and Income Distribution. Geneva: International Labour Office.

Kuo, Shirley W. Y. 1983. The Taiwan Economy in Transition. Boulder, Colo.: Westview Press.

Kuznets, Paul. 1988. "An East Asian Model of Economic Development: Japan, Taiwan, and South Korea." Economic Development and Cultural Change 36(Supplement, April): S11-43.

Kwark, Noh-Sun, and Changyong Rhee. 1992. "Educational Wage Differentials in Korea." Working Paper 318 (March). Rochester Center for Economic Research, Rochester, N.Y. Processed.

Leipziger, Danny. 1992. "Korea: Issues of Distribution." Paper presented at the Symposium on MicroSocial Issues in South Korea. University of California at San Diego, June. World Bank, Latin America and the Caribbean Country Department IV, Washington, D.C. Processed.

Lewis, W. Arthur. 1954. "Development with Unlimited Supplies of Labour." Manchester School 22(May):139-91.

Li, K. T. 1989. The Evolution of Policy behind Taiwan's Development Success. New Haven, Conn.: Yale University Press.

Lim, Linda Y. C. 1990. "Singapore." In Stephen Herzenberg and Jorge F. Perez-Lopez, eds., Labor Standards and Development in the Global Economy. Washington, D.C.: U.S. Department of Labor.

Lin, Chung-Cheng. 1989. "Economics of Unions: Taiwan's Case Study." Self-published. Processed.

Lindauer, David L. 1984. "Labor Market Behaviour in the Republic of Korea." World Bank Staff Working Paper 641. World Bank, Washington D.C. Processed.

------. 1991. Korea: The Strains of Economic Growth. Cambridge, Mass.: Harvard Institute for International Development.

Mazumdar, Dipak. 1990. "Korea's Labor Markets under Structural Adjustment." World Bank Working Paper 554. World Bank, Africa Regional Office, Washington, D.C. Processed.

Moran, Ricardo. 1976. "Labor Availability and Employment." In Parvez Hasan, ed., Korea: Problems and Issues in a Rapidly Growing Economy. Baltimore, Md.: Johns Hopkins University Press.

Nam, Sang-Woo. 1984. "Korea's Stabilization Efforts since the Late 1970's." Korea Development Institute Working Paper 8405. Korea Development Institute, Seoul. Processed.

Pang, Eng-Fong. 1988. Labour Market Developments and Structural Change: The Experience of ASEAN and Australia. Singapore: Singapore University Press.

Pang, Eng-Fong, and Linda Y. C. Lim. 1989. "Wage Policy in Singapore." In International Labour Office, Government Wage Policy Formulation in Developing Countries: Seven Country Studies. Geneva.

Park, Fun-Koo, and Young-Bum Park. 1991. "Korea's Industrial Relations Developments since the 1987 Democratization Declaration: Main Features and Issues:' Korea Labor Institute, Seoul. Processed.

Park, Se-II. 1980. "Wages in Korea: Determination of the Wage Levels and the Wage Structure in a Dualistic Labor Market." Ph.D. diss., Cornell University. Ithaca, N.Y. Processed.

-----. 1993. "The Role of the State in Industrial Relations: The Case of Korea." Comparative Labor Law Journal 14(3):321-38.

Park, Young-Bum. 1992a. "State Regulations, the Labor Market and Economic Development: Korea." Paper presented at the Conference on Labour Institutions and Economic Development in Asia, Bali, February. Korea Labor Institute, Seoul. Processed.

-----. 1992b. "Wage-Fixing Institutions in South Korea." Korea Labor Institute Working Paper. Korea Labor Institute, Seoul. Processed. 
Rabushka, Alvin. 1979. Hong Kong: A Study in Economic Freedom. Chicago: University of Chicago, Graduate School of Business.

Richardson, Ray, and Whan-Byung Kim. 1985. "The Structure of Labour Markets in LDCS: Overview for South Korea, 1953-1984." Paper prepared for the World Bank, Employment and Income Distribution Division, Washington, D.C. Processed.

Topel, Robert, and Dae-II Kim. 1992. "Labor Markets and Economic Growth: Lessons from Korea's Industrialization, 1970-1990." Paper presented at the Universities Re- search Conference: The Labor Market in International Perspective, National Bureau of Economic Research, Cambridge, Mass., April. Cambridge, Mass.: NBER.

Turner, H. A. 1980. The Last Colony: But Whose? New York: Cambridge University Press.

Vogel, Ezra, and David L. Lindauer. 1991. "Toward a Social Compact for Korean Labor." In David L. Lindauer, Korea: The Strains of Economic Growth. Cambridge, Mass.: Harvard Institute for International Development.

Wu, Rong-I. 1986. "Taiwan's Industrialization." In Institute of Strategic and International Studies, ed., Lessons from Taiwan: Pathways to Follow and Pitfalls to Avoid. Kuala Lumpur: 1s1s.

You, Jong-II. 1990. "South Korea." In Stephen Herzenberg and Jorge F. Perez-Lopez, eds., Labor Standards and Development in the Global Economy. Washington, D.C.: U.S. Department of Labor.

-----. 1992. "Labour Institutions and Economic Development in South Korea." Paper presented at the conference Labour Institutions and Economic Development in Asia, Bali, February. International Institute for Labour Studies. Geneva. Processed.

Young, Alwyn. 1989. "Hong Kong." In Ronald Findlay and Stanislaw Wellisz, eds., The Political Economy of Poverty, Equity, and Growth: Five Small Countries. Washington, D.C.: World Bank. 